\title{
Morpho-agronomic characters of oat growing with humic acid and zinc application in different sowing times
}

\author{
Imren Kutlu ${ }^{1^{*}} \&$ Nurdilek Gulmezoglu ${ }^{2}$ \\ ${ }^{1}$ Department of Biosystem Engineering, Faculty of Agriculture, Eskisehir Osmangazi University, Eskisehir-Turkey \\ ${ }^{2}$ Department of Soil Science and Plant Nutrition, Faculty of Agriculture, Eskisehir Osmangazi University, Eskisehir-Turkey \\ *Email: ikutlu@ogu.edu.tr
}

\section{ARTICLE HISTORY}

Received: 09 July 2020

Accepted: 22 September 2020

Published: 01 October 2020

\section{KEYWORDS}

Agronomic efficiency

Avena sativa

Cold tolerance

Soil conditioner

Yield component

\section{ABSTRACT}

The objectives of the study were to determine the effects of humic acid (HA) and zinc ( $\mathrm{Zn}$ ) applications on winter tolerance and yield performance of oat (cv. Albatros) planted in winter and spring sowing times (ST). We conducted the study in the 2017/2018 growing season. The experimental layout was split-split plots with three replications. Sowing times (winter and spring) comprised of the main plots. Humic acid application (with $\mathrm{HA}$ and without $\mathrm{HA}$ ) was in the sub-plots, and $\mathrm{Zn}$ application rates $(0,23$ and $46 \mathrm{~kg} \mathrm{ha}^{-1}$ ) were in the sub-sub-plots. Chlorophyll content of plants was measured at the heading stage, while plant height, panicle height, panicle weight, number of grain per panicle, weight of grains per panicle, harvest index and grain yield were determined at the harvest. The effects of HA and $\mathrm{Zn}$ applications in both ST increased the chlorophyll content, yield and yield components. The results showed that cold tolerance of oat plants can be increased by the application of $\mathrm{HA}$ and $46 \mathrm{~kg}$ $\mathrm{ZnSO}_{4} .7 \mathrm{H}_{2} \mathrm{O}$ ha ${ }^{-1}$. Overall performance of winter season was better than spring; thus, oat can be cultivated in winter under warm winter climate conditions. In addition, the HA and $\mathrm{Zn}$ applications can be used for other cold sensitive plant species to increase the cold tolerance which is a prevalent environmental stress affecting productivity of crops.

\section{Introduction}

Oat (Avena sativa L.) is cultivated commonly as a forage crop because of the high nutritional value compared to the other cereals. The oat contains useful nutrients for human and animal health $(1,2)$. Besides the value as forage for animal and food for human, the oat has recently gained a considerable importance for the pharmaceutical and cosmetic industries (1). Despite the increasing demand, the cultivation area of oat is not expanding sufficiently to produce adequate oat for the market (3). The main reasons for the lack of widespread oat cultivation are because of the low grain yield, problems of cold and drought sensitivity, lodging, grain losses and non-simultaneous grain ripening (2). The oat is commonly planted in spring in the Central Anatolia Region of Turkey because of the drought and cold sensitivity of oat. However, irregular and inadequate precipitation in the spring with a short vegetation period affect negatively the yield of oat (1).
Using chemical fertilisers alone will not increase the fertility of soils and improve the resistance of plants to stress conditions and diseases. Therefore, the application of humic acid (HA) recently become common in addition to the use of mineral fertilizers. The amino acid composition of HA increases the population and activity of soil microorganisms and improves plant growth. The molecules in HA bind nutrients and prevents leaching from the root zone, and help plant roots receive water and nutrients (4). The HA stimulate the root development in early plant development stages (5). At the same time, HA control the presence of nutrients and enhance their reception by the plant through increasing the ATPaze activity between soil and atmosphere and transfer between carbondioxide and oxygen (6). In general, metal ion complexes that increase the micronutrients [especially iron (Fe) and zinc (Zn)] availability with low solubility are affected by HA on plant nutrition (7).

(c) Kutlu \& Gulmezoglu (2020). This is an open-access article distributed under the terms of the Creative Commons Attribution License, which permits unrestricted use, distribution and reproduction in any medium, provided the original author and source are credited (https://creativecommons.org/licenses/by/4.0/)

To cite this article: Kutlu I, Gulmezoglu N. Morpho-agronomic characters of oat growing with humic acid and zinc application in different sowing times . Plant Science Today. 2020;7(4):594-600. https://doi.org/10.14719/pst.2020.7.4.861 
High soil $\mathrm{pH}$ in the presence of calcium carbonate decreases the mobility of micronutrients, causing deficiency in many micronutrients including $\mathrm{Zn}$ and Fe (8). Zinc deficiency in cereal-grown soils of Central Anatolia is one of the major causes that restrict crop yield. The sensitivity of plants to environmental stress conditions such as drought, high or low temperature etc increases in $\mathrm{Zn}$ deficiency. Therefore, the plants are still stunted and the yield is greatly reduced (9). When there is $\mathrm{Zn}$ inadequacy in the development stage, photosynthesis rate decreases to $50-70 \%$ depending on the plant type and $\mathrm{Zn}$ content in the soil (10). In addition, $\mathrm{Zn}$ play important roles on water use efficiency of the plant, root development and growth as well as flowering and grain formation. The winter death in seedlings, seeds with low $\mathrm{Zn}$ content is more common, especially in the soil which lacks of $\mathrm{Zn}$ (8). The positive effects of $\mathrm{Zn}$ on photosynthesis, starch accumulation, sucrose synthesis and integrity and durability of biological membranes (9).

Winter cereals survive the winter months with no damage when the seedlings have a minimum of 45 leaves and one or two tillers to store enough energy. The application of $\mathrm{Zn}$ and HA may have a positive influence on the growth and development of oat plants, and help to increase the cold stress resistance in winter months. Therefore, this study was designed to investigate the effects of HA and $\mathrm{Zn}$ applications to the soil on cold stress tolerance and some morpho-agronomic characters of oat grown in a Zn deficient soil of central Anatolia.

\section{Materials and Methods}

\section{Site description}

We established the field experiment on the research fields of Faculty of Agriculture, Eskisehir Osmangazi University, Turkey in the 2017/2018 growing season. The climatic data (monthly total rainfall, average temperature and relative humidity) of the trial area as growing season (2017/2018) and long years (1939 to 2017) are given in Table 1 . Total rainfall during the growing season, average temperature and humidity values were higher than the long-term mean values, especially since the winter months were unusually temperature. The experimental soil was slightly alkaline, non-saline and clay-loamy textured. Organic matter, Mn and Zn contents were low, while $\mathrm{K}$, Fe, P, $\mathrm{Cu}$ and lime contents were sufficient (Table 2). Fifteen days after the application of HA, Zn and basic fertilisation, soil samples were taken from each application again and analysed (Table 2).

\section{Experimental materials and design}

Oat seed (cv. Albatros) was obtained from Ata Seed Company, Turkey. Albatros has plump white grain. It has short vegetation period and is generally spring planted. However, it is also recommended for planting in winter in temperate regions.

Humic acid material used in the study was a commercially available natural organic soil conditioner (TKI-Humas) containing humic and fulvic acids extracted from leonardit. Zinc sulphate
(ZnSO $_{4} .7 \mathrm{H}_{2} \mathrm{O}$ ) fertiliser containing $22 \% \mathrm{Zn}$ was used in $\mathrm{Zn}$ application.

The experimental layout was a randomised complete block design with split-split plots in three replications. Main plots (sowing time; winter and spring) were divided into two sub-plots and two HA application (with HA or without HA) were randomly allocated to these. Sub-plots viz. with HA and without HA were then divided into three sub-sub-plots and some of them were not treated with Zn fertilizer, to some were applied $23 \mathrm{~kg} \mathrm{ZnSO} \mathrm{Zn}_{4} \cdot 7 \mathrm{H}_{2} \mathrm{O} \mathrm{ha} \mathrm{h}^{-1}$ and others $46 \mathrm{~kg} \mathrm{ZnSO} \mathrm{Zn}_{4} .7 \mathrm{H}_{2} \mathrm{O}$ ha $^{-1}$ (Fig. 1). Each sub-sub-plots comprised of $1.2 \times 4 \mathrm{~m}$ size. Zinc and HA were not applied to the control plots.

The HA (20 L ha-1) was applied to the soil surface considering the recommendations of the produce company (TKI Humas) using a mechanical sprayer 24 hours before planting and thoroughly mixed in the sowing deep.

Zinc was applied to soil before planting using a mechanical sprayer at a rate of $23 \mathrm{~kg} \mathrm{ZnSO} 4.7 \mathrm{H}_{2} \mathrm{O} \mathrm{ha}^{-1}$ as an optimum dose for Central Anatolian (11) and 46 $\mathrm{kg} \mathrm{ZnSO} 4.7 \mathrm{H}_{2} \mathrm{O}$ ha $^{-1}$ as high dose.

The $31.3 \mathrm{~kg} \mathrm{~N}$ and $35.2 \mathrm{~kg} \mathrm{P}$ per ha were applied as di-ammonium phosphate (18-46-0) at the time of sowing and $28.7 \mathrm{~kg} \mathrm{~N} \mathrm{ha}^{-1}$ as ammonium sulphate (21$0-0-24)$ was added to complete $60 \mathrm{~kg} \mathrm{ha}^{-1}$ of $\mathrm{N}$. Nitrogen topdressing was then applied as $60 \mathrm{~kg} \mathrm{~N}$ per ha as ammonium sulphate (21-0-0-24) during the tillering stage.

Oat seeds (cv. Albatros) as 500 seeds $\mathrm{m}^{-2}$ were planted by a small plot seeder (Turan Machine, Turkey) in $24^{\text {th }}$ of October and $20^{\text {th }}$ of March for winter and spring oat cultivations respectively.

The field was irrigated after planting in both ST to help emergence. The plants were irrigated again during stem elongation and flowering periods. Thus, total $300 \mathrm{~mm}$ of water were applied.

\section{Measurements}

Chlorophyll content was measured in the flag leaves using a chlorophyll meter (Spectrum Field Scout CM 1000, Spectrum Technologies, Inc.) at the heading stage. Yield and quality parameters such as plant height, panicle length, panicle weight, number of grains per panicle, grain weight per panicle, harvest index, grain yield and thousand-grain weight were also determined.

Agronomic zinc efficiency (AE) was calculated using the equation (12);

$$
\mathrm{AE}=(\mathrm{Yf}-\mathrm{Yc}) / \mathrm{F}
$$

where, $\mathrm{AE}$ is the agronomic efficiency (\%), Yf is the grain yield ( $\mathrm{t} \mathrm{ha} \mathrm{a}^{-1}$ ) with fertilizer treatments, Yc is the grain yield ( $\mathrm{t} \mathrm{ha}^{-1}$ ) without fertiliser treatment, and $\mathrm{F}$ is the amount of $\mathrm{Zn}$ added to the soil $\left(\mathrm{kg} \mathrm{ha}^{-1}\right)$.

\section{Statistical analyses}

The data got from the experiment were analyzed using general linear model (GLM) procedure with IBM-SPSS 20 statistical package programme. The means were compared using the Duncan test at 
$\mathrm{p} \leq 0.05$ and the interactions of applications and genotypes were shown in graphs. significantly differed for all the traits. The effect of ST

$\times$ HA interaction on yield and yield parameters such

Table 1. Climatic conditions in growing season and long years at experimental area

\begin{tabular}{|c|c|c|c|c|c|c|}
\hline & \multicolumn{3}{|c|}{ Growing Season (2017-2018) } & \multicolumn{3}{|c|}{ Long Years (1993-2017) } \\
\hline & $\begin{array}{l}\text { Total rainfall } \\
\text { (mm) }\end{array}$ & $\begin{array}{l}\text { Mean humidity } \\
\text { (\%) }\end{array}$ & $\begin{array}{c}\text { Mean temperature } \\
\left({ }^{\circ} \mathrm{C}\right)\end{array}$ & $\begin{array}{c}\text { Total rainfall } \\
\text { (mm) }\end{array}$ & $\begin{array}{c}\text { Mean humidity } \\
(\%)\end{array}$ & $\begin{array}{c}\text { Mean temperature } \\
\left({ }^{\circ} \mathrm{C}\right)\end{array}$ \\
\hline October & 48.4 & 72.9 & 10.7 & 31.6 & 64.7 & 11.8 \\
\hline November & 28.6 & 85.4 & 5.5 & 29.8 & 70.5 & 5.6 \\
\hline December & 41.8 & 86.3 & 3.9 & 42.0 & 75.9 & 1.6 \\
\hline January & 29.0 & 86.3 & 1.6 & 37.6 & 75.2 & -0.2 \\
\hline February & 41.6 & 82.4 & 5.8 & 29.2 & 70.6 & 0.9 \\
\hline March & 41.1 & 73.2 & 9.3 & 32.5 & 64.2 & 4.8 \\
\hline April & 9.5 & 61.6 & 13.8 & 41.6 & 62.7 & 9.6 \\
\hline May & 92.5 & 74.9 & 16.7 & 46.5 & 59.5 & 14.6 \\
\hline June & 73.8 & 69.6 & 19.9 & 25.6 & 55.2 & 19.1 \\
\hline July & 60.1 & 65.7 & 22.2 & 13.2 & 51.9 & 22 \\
\hline Mean & & 75.83 & 10.94 & & 65.0 & 9.0 \\
\hline Total & 466.4 & & & 329.7 & & \\
\hline
\end{tabular}

Table 2. Soil properties of research area

\begin{tabular}{|c|c|c|c|c|c|c|}
\hline \multirow[b]{2}{*}{ Characters } & \multicolumn{3}{|c|}{ Without HA } & \multicolumn{3}{|c|}{ With HA } \\
\hline & $0 \mathrm{Zn}$ & $23 \mathrm{Zn}$ & $46 \mathrm{Zn}$ & $0 \mathrm{Zn}$ & $23 \mathrm{Zn}$ & $46 \mathrm{Zn}$ \\
\hline$\overline{\mathrm{pH}}$ & 8.1 & 8.0 & 8.0 & 8.1 & 7.9 & 7.9 \\
\hline Salt (\%) & 0.01 & 0.02 & 0.02 & 0.02 & 0.01 & 0.02 \\
\hline Lime (\%) & 7.1 & 7.9 & 5.5 & 7.9 & 8.7 & 8.3 \\
\hline Organic matter (\%) & 0.94 & 1.09 & 1.59 & 1.29 & 1.50 & 1.68 \\
\hline $\mathrm{P}_{2} \mathrm{O}_{5}\left(\mathrm{~kg} \mathrm{ha}^{-1}\right)$ & 64.7 & 130.3 & 309.4 & 146 & 180.9 & 146.4 \\
\hline $\mathrm{K}_{2} \mathrm{O}\left(\mathrm{kg} \mathrm{ha}^{-1}\right)$ & 5651 & 4774 & 6108 & 3615 & 4724 & 2928 \\
\hline Fe (mg kg-1) & 6.10 & 6.58 & 6.78 & 7.93 & 7.41 & 6.44 \\
\hline Mn (mg kg-1) & 10.5 & 11.2 & 8.1 & 11.2 & 11.4 & 9.7 \\
\hline Zn (mg kg-1) & 0.87 & 3.03 & 3.35 & 1.13 & 3.31 & 4.47 \\
\hline $\mathrm{Cu}\left(\mathrm{mg} \mathrm{kg}^{-1}\right)$ & 2.10 & 1.52 & 1.65 & 1.91 & 1.86 & 1.80 \\
\hline
\end{tabular}

\begin{tabular}{|c|c|c|c|c|c|}
\hline \multicolumn{6}{|c|}{ Main plot 1: Winter sowing } \\
\hline \multicolumn{3}{|c|}{ Sub plot 1: Without HA } & \multicolumn{3}{|c|}{ Sub plot 2: With HA } \\
\hline $\begin{array}{c}\text { Sub sub plot 1: } \\
0 \mathrm{Zn}\end{array}$ & $\begin{array}{c}\text { Sub sub plot } 2: \\
23 \mathrm{Zn}\end{array}$ & $\begin{array}{c}\text { Sub sub plot } 3: \\
46 \mathrm{Zn}\end{array}$ & $\begin{array}{c}\text { Sub sub plot } 1: \\
0 \mathrm{Zn}\end{array}$ & $\begin{array}{c}\text { Sub sub plot 2: } \\
23 \mathrm{Zn}\end{array}$ & $\begin{array}{c}\text { Sub sub plot 3: } \\
46 \mathrm{Zn}\end{array}$ \\
\hline \multicolumn{6}{|c|}{ Main plot 2: Spring sowing } \\
\hline \multicolumn{3}{|c|}{ Sub plot 1: Without HA } & \multicolumn{3}{|c|}{ Sub plot 2: With HA } \\
\hline $\begin{array}{c}\text { Sub sub plot 1: } \\
0 \mathrm{Zn}\end{array}$ & $\begin{array}{l}\text { Sub sub plot 2: } \\
23 \mathrm{Zn}\end{array}$ & $\begin{array}{c}\text { Sub sub plot 3: } \\
46 \mathrm{Zn}\end{array}$ & $\begin{array}{c}\text { Sub sub plot } 1: \\
0 \mathrm{Zn}\end{array}$ & $\begin{array}{c}\text { Sub sub plot 2: } \\
23 \mathrm{Zn}\end{array}$ & $\begin{array}{c}\text { Sub sub plot 3: } \\
\qquad 6 \mathrm{Zn}\end{array}$ \\
\hline
\end{tabular}

Fig. 1. Experimental design of the study.

\section{Results and Discussion}

The influences of HA and $\mathrm{Zn}$ applications to soil on some physical and chemical properties of the experimental soil are shown in Table 2. Lime and salt contents and $\mathrm{pH}$ of soil have not changed with the HA and $\mathrm{Zn}$ applications, however organic matter content and nutritional composition of soil significantly changed. The organic matter and $\mathrm{Zn}$ contents of soil increased with the increase in $\mathrm{Zn}$ application doses, and the increase in organic matter content was higher in HA applications. These findings showed that the addition of HA could increase the available plant nutrient ion content of the soil, especially enhance the content of soil organic matter, which is helpful to the recovery of crop growing soil. Similar results found other researchers $(13,14)$.

Sowing time had a significant $(p<0.01)$ effect on all traits examined except plant height and panicle length, while the effects of HA and $\mathrm{Zn}$ applications as panicle weight was significantly different. The effects of other interactions on the traits determined were not statistically significant (Table 3).

The chlorophyll content and the values of yield and yield parameters determined for winter sowing were higher than those recorded in spring sowing. Application of HA and Zn increased the chlorophyll content and improved the yield parameters. The improvement in properties studied with $\mathrm{Zn}$ applications was in good agreement with the increasing doses of Zn to soil (Table 4).

The results of variance analysis indicated that the effects of treatments on chlorophyll content were insignificant however; the chlorophyll content increased with the increasing $\mathrm{Zn}$ doses in winter sowing. The increase in chlorophyll content was even higher in HA treatments (Fig. 2). In spring sowing, chlorophyll content in $23 \mathrm{~kg}$ of $\mathrm{Zn} \mathrm{ha}{ }^{-1}$ dose and HA application increased by $26 \%$ compared to control. High chlorophyll content of leaves indicates of higher 
photosynthesis and yield (15). Earlier studies $(16,17)$ indicated that the chlorophyll content significantly decreased depending on environmental factors such as temperature, precipitation, drought etc. The no significant difference between sowing times as expected. It was reported that the absorption rate of mineral ions on root surfaces and their transfer into the plant tissue cells are enhanced with the

Table 3. Mean squares obtained from variance analysis of investigated traits

\begin{tabular}{llccccccccc}
\hline SOV & Df & Chl & PH & PL & PW & GNP & GWP & TKW & HI & GY \\
\hline ST & 1 & $77469.44^{* *}$ & $4.20^{\text {ns }}$ & $0.27^{\text {ns }}$ & $9.41^{* *}$ & $16030.94^{* *}$ & $9.43^{* *}$ & $185.28^{* *}$ & $847.10^{* *}$ & $11.94^{* *}$ \\
\hline HA & 1 & $17689.00^{*}$ & $573.60^{* *}$ & $51.60^{* *}$ & $6.66^{* *}$ & $3678.83^{* *}$ & $4.47^{* *}$ & $319.75^{* *}$ & $278.83^{*}$ & $14.42^{* *}$ \\
\hline Zn & 2 & $16660.58^{*}$ & $163.97^{*}$ & $11.99^{*}$ & $3.74^{* *}$ & $2509.43^{* *}$ & $2.06^{* *}$ & $172.35^{* *}$ & $345.59^{* *}$ & $13.28^{* *}$ \\
\hline ST $\times$ HA & 1 & $544.44^{\text {ns }}$ & $44.67^{\text {ns }}$ & $0.03^{\text {ns }}$ & $1.04^{*}$ & $110.67^{\text {ns }}$ & $0.46^{\text {ns }}$ & $50.10^{\text {ns }}$ & $22.36^{\text {ns }}$ & $1.10^{\text {ns }}$ \\
\hline ST $\times$ Zn & 2 & $7783.69^{\text {ns }}$ & $18.31^{\text {ns }}$ & $7.07^{\text {ns }}$ & $0.44^{\text {ns }}$ & $943.74^{\text {ns }}$ & $0.24^{\text {ns }}$ & $6.49^{\text {ns }}$ & $1.17^{\text {ns }}$ & $0.02^{\text {ns }}$ \\
\hline HA $\times$ Zn & 2 & $1535.08^{\text {ns }}$ & $13.19^{\text {ns }}$ & $0.09^{\text {ns }}$ & $0.23^{\text {ns }}$ & $117.65^{\text {ns }}$ & $0.04^{\text {ns }}$ & $15.79^{\text {ns }}$ & $25.04^{\text {ns }}$ & $0.13^{\text {ns }}$ \\
\hline ST $\times$ HA $\times$ Zn & 2 & $1610.53^{\text {ns }}$ & $92.93^{\text {ns }}$ & $0.54^{\text {ns }}$ & $0.22^{\text {ns }}$ & $125.28^{\text {ns }}$ & $0.18^{\text {ns }}$ & $19.47^{\text {ns }}$ & $13.20^{\text {ns }}$ & $0.07^{\text {ns }}$ \\
\hline Error & 24 & 3161.92 & 51.07 & 2.66 & 0.23 & 171.16 & 0.15 & 14.26 & 50.35 & 0.58 \\
\hline
\end{tabular}

*Chl: chlorophyll content; PH: plant height; PL: panicle length; PW: panicle weight; GNP: grain number per panicle; GWP: grain weight per panicle; HI: harvest index; GY: grain yield; TKW: thousand kernel weight; SOV: source of variance; ST: sowing time; HA: humic acid applications; Zn: zinc fertilization.

change of climatic and environmental characteristics depending on the sowing time (season) of the plants affected the chlorophyll content. Since Zn participates in chlorophyll production, the deficiency of Zn negatively affects the chlorophyll content of leaves $(18,19)$. Therefore, the application of a moderate amount of $\mathrm{Zn}$ increases the chlorophyll contents in tissue, promotes the development of supplement of HA in soil which also yields to a raise in the plant height. Therefore, more active metabolism and high respiratory activity and higher plant height are observed (28). The parameters directly affecting the grain yield such as panicle weight, grain number in a panicle, grain weight in a panicle and thousand grain weight significantly increased in $46 \mathrm{~kg} \mathrm{Zn} \mathrm{ha}^{-1}$ application dose especially

Table 4. The mean values of sowing time, humic acid, zinc applications and genotype mean belonging examined traits

\begin{tabular}{|c|c|c|c|c|c|c|c|}
\hline & \multicolumn{2}{|c|}{ Sowing time } & \multicolumn{2}{|c|}{ Humic acid } & \multicolumn{3}{|c|}{ Zinc doses (kg ha-1) } \\
\hline & Winter & Spring & Without HA & With HA & $\mathbf{0}$ & 23 & 46 \\
\hline Chl (CM) & $494.06 \pm 58.8$ & $401.28 \pm 72.9$ & $425.50 \pm 82.7$ & $469.83 \pm 73.9$ & $405.42 \pm 76.0$ & $461.75 \pm 64.4$ & $475.83 \pm 87.5$ \\
\hline CV\% & 11.91 & 18.18 & 19.43 & 15.74 & 18.75 & 13.94 & 18.40 \\
\hline $\mathrm{PH}(\mathrm{cm})$ & $91.91 \pm 7.79$ & $91.22 \pm 9.04$ & $87.57 \pm 5.99$ & $95.56 \pm 8.54$ & $87.64 \pm 7.90$ & $92.07 \pm 6.75$ & $94.98 \pm 9.09$ \\
\hline CV\% & 8.47 & 9.91 & 6.85 & 8.94 & 9.01 & 7.33 & 9.57 \\
\hline $\mathrm{PL}(\mathrm{cm})$ & $19.39 \pm 2.40$ & $19.57 \pm 1.83$ & $18.28 \pm 1.60$ & $20.68 \pm 1.88$ & $18.37 \pm 1.68$ & $19.78 \pm 2.03$ & $20.30 \pm 2.23$ \\
\hline$\overline{\mathrm{CV} \%}$ & 12.36 & 9.37 & 8.77 & 9.07 & 9.16 & 10.26 & 10.99 \\
\hline PW (g) & $3.85 \pm 1.04$ & $2.83 \pm 0.49$ & $2.91 \pm 0.69$ & $3.77 \pm 1.01$ & $2.81 \pm 0.80$ & $3.29 \pm 0.72$ & $3.92 \pm 1.03$ \\
\hline CV\% & 27.03 & 17.24 & 23.57 & 26.69 & 28.34 & 21.85 & 26.34 \\
\hline GNP & $112.18 \pm 25.88$ & $69.98 \pm 15.15$ & $80.97 \pm 26.73$ & $101.19 \pm 30.20$ & $75.66 \pm 19.76$ & $93.25 \pm 25.05$ & $104.33 \pm 37.10$ \\
\hline CV\% & 23.07 & 21.65 & 33.01 & 29.84 & 26.12 & 26.86 & 35.52 \\
\hline GWP (g) & $3.10 \pm 0.79$ & $2.09 \pm 0.42$ & $2.24 \pm 0.65$ & $2.95 \pm 0.82$ & $2.18 \pm 0.74$ & $2.59 \pm 0.65$ & $3.00 \pm 0.86$ \\
\hline CV\% & 25.35 & 20.08 & 28.92 & 27.72 & 34.01 & 25.13 & 28.57 \\
\hline TKW (g) & $32.38 \pm 7.19$ & $27.84 \pm 3.92$ & $27.13 \pm 4.34$ & $33.09 \pm 6.35$ & $26.34 \pm 5.04$ & $30.06 \pm 3.66$ & $33.92 \pm 7.10$ \\
\hline CV\% & 22.22 & 14.07 & 15.99 & 19.20 & 19.13 & 12.16 & 20.93 \\
\hline HI (\%) & $41.75 \pm 7.86$ & $32.05 \pm 8.50$ & $34.11 \pm 9.08$ & $39.68 \pm 9.22$ & $30.70 \pm 9.27$ & $39.81 \pm 7.29$ & $40.18 \pm 9.08$ \\
\hline CV\% & 18.83 & 26.53 & 26.63 & 23.24 & 30.18 & 18.31 & 22.60 \\
\hline GY $\left(t^{h} a^{-1}\right)$ & $5.81 \pm 1.39$ & $4.66 \pm 1.18$ & $4.61 \pm 1.18$ & $5.87 \pm 1.34$ & $4.37 \pm 0.95$ & $4.94 \pm 1.12$ & $6.41 \pm 1.28$ \\
\hline CV\% & 23.86 & 25.32 & 25.59 & 22.76 & 21.66 & 22.74 & 20.01 \\
\hline
\end{tabular}

*Chl: Chlorophyll content; PH: plant height; PL: panicle length; PW: panicle weight; GNP: grain number per panicle; GWP: grain weight per panicle; HI: harvest index; GY: grain yield; TKW: thousand kernel weight.

aboveground parts, such as leaves and increases the biomass $(20,21)$. Higher biomass indirectly improves the water absorption of roots and offers a larger surface area for photosynthesis. The positive effects of $\mathrm{Zn}$ on photosynthesis cause a significant increase in crop yield $(22,23)$. Several researchers have reported the improving effect of HA on the chlorophyll content of leaves (24-26).

Plant height and panicle length which are known as significant seconder yield components of crop plants have not been affected by ST. While they are also known to be inherited quantitatively, a lack of water supply can prevent their full expression (27). Since oat plants find the water required for their growth both in spring and winter sowing, there was with HA treatment at winter sowing. Similarly, previous studies also showed that crop yield in $\mathrm{Zn}$ deficient soils significantly increased with the $\mathrm{Zn}$ application to soil $(8,29,30)$.

The response of yield characteristics to HA and Zn applications was poor in spring sowing. However, the values obtained were close to those got without HA application in winter sowing. The harvest index values calculated in $23 \mathrm{~kg} \mathrm{Zn} \mathrm{ha}^{-1}$ application treated with and without HA at winter sowing were close to each other. The HA and $\mathrm{Zn}$ applications increased the harvest index of oats in spring sowing. Humic acid, a naturally available substance is a cheap source of organic matter that enhances soil fertility, availability of nutrients and water holding capacity 


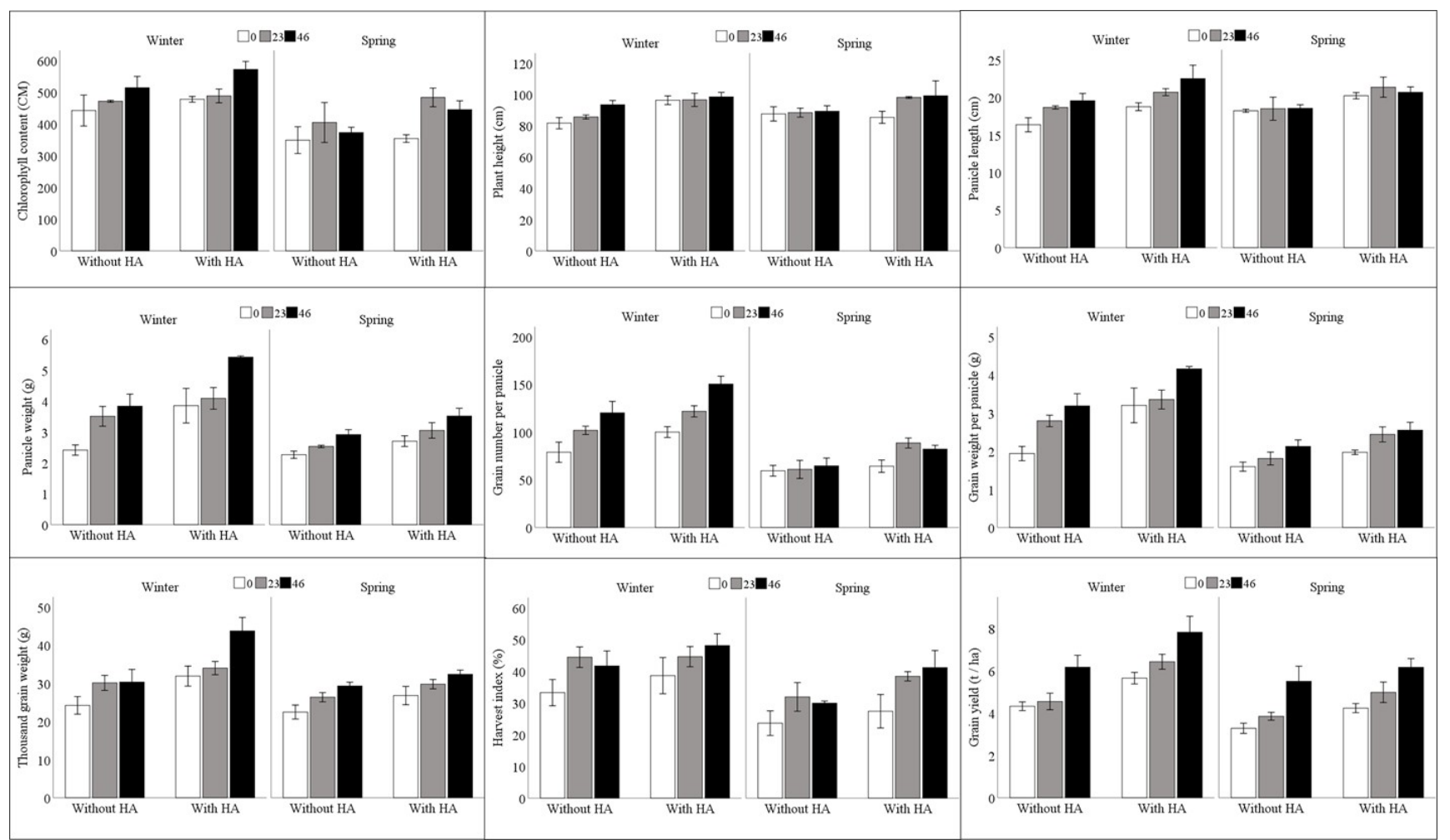

Fig. 2. Change of yield and yield components of oat according to sowing time, humic acid and zinc applications.

of soils. Therefore, the application of HA provides a favourable environment for plant growth, improves the yield parameters and results in higher crop yield (31). In addition, an earlier study (32) reported that liquid humic application increased the winter tolerance of wheat by improving the growth and physiological indices during autumn acclimation in organic and conventional farming systems.

The application of $23 \mathrm{~kg} \mathrm{Zn}$ ha-1 with and without HA in winter sowing slightly increased the oat yield compared to the control. However, oat yield increased in $46 \mathrm{~kg}$ Zn ha-1 application dose by $30 \%$ compared to the control. In spring sowing, the increase in each $\mathrm{Zn}$ dose with HA treatments increased the oat yield approximately by $15 \%$ compared to the control (Fig. 2). The results of this study revealed that single or combined applications of $\mathrm{HA}$ and $\mathrm{Zn}$ improved the yield and yield characteristics of oat. The stimulating effect of both $\mathrm{HA}$ and $\mathrm{Zn}$ is partly associated with the higher uptake of mineral nutrients (33). Similarly, positive effects of HA and Zn application on the yield of different crops such as pearl millet $(34)$, wheat $(30,31,35,36)$ and sunflower (37) have been reported in other studies. In some studies, it has been shown that 5 or $10 \mathrm{~kg} \mathrm{Zn}$ $\mathrm{ha}^{-1}\left(\sim 25-50 \mathrm{~kg} \mathrm{ZnSO}_{4} .7 \mathrm{H}_{2} \mathrm{O}\right)$ application is sufficient for high yield of cereals $(38,39)$. Similar results were obtained in this study.

The agronomic efficiency of $\mathrm{Zn}$ application in respect to sowing times and HA application indicated that agronomic efficiency positively affected by the HA application in winter sowing. The agronomic efficiency of $\mathrm{Zn}$ increased with the application of HA in both sowing times, except for $46 \mathrm{~kg} \mathrm{Zn} \mathrm{ha}{ }^{-1}$ in spring sowing. Considering the $\mathrm{Zn}$ doses, the agronomic efficiency of $46 \mathrm{~kg} \mathrm{Zn} \mathrm{ha}^{-1}$ was higher (Fig. 3). Total Zn content of the soil with Zn application in this study is sufficient, because optimum level of available $\mathrm{Zn}$ in soil changes between 2 and $20 \mathrm{mg} \mathrm{kg}^{-1}$ (40). However, in general, the factors of high calcium carbonate content, high soil $\mathrm{pH}$ values, low organic matter content of soils and high phosphorus concentration may prevent the Zn uptake through roots. Humic acid increases the availability of micro and macro nutrients by increasing the organic matter content of soils. Humic acid act as a bridge between nutrients in the soil and the plant roots, as reported in another study (41) that application of HA substances to soil increases the uptake of chelated micronutrients. The agronomic efficiency of $\mathrm{Zn}$ values calculated in this study reveals the benefits of HA application in winter sowing.

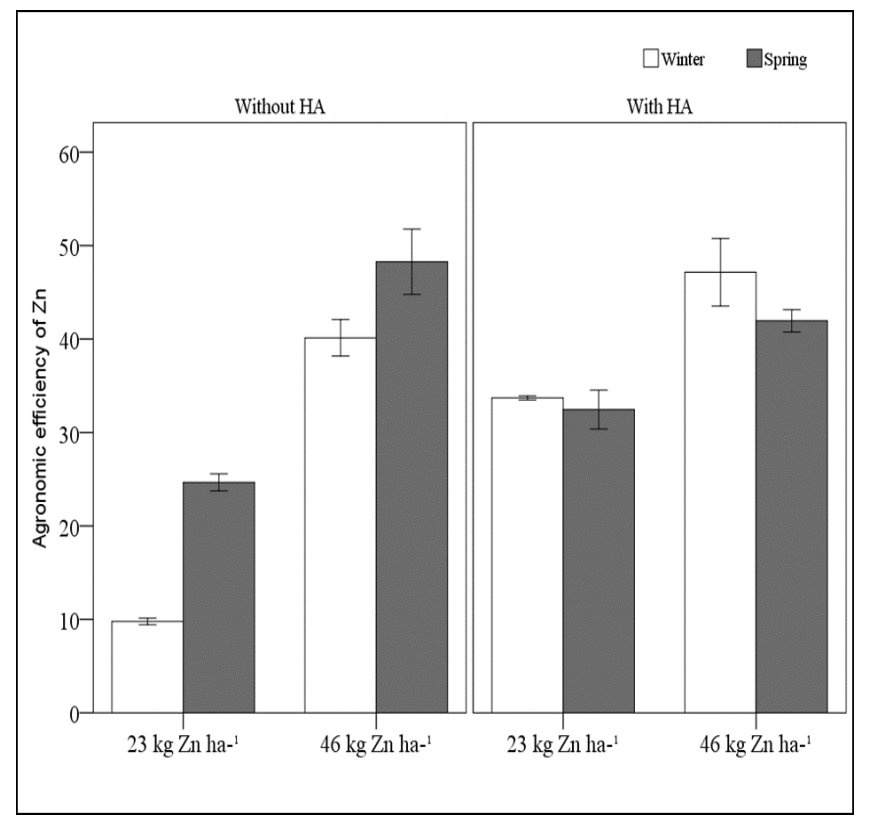

Fig. 3. Agronomic efficiency of $\mathrm{Zn}\left(\mathrm{ZnSO}_{4} \cdot 7 \mathrm{H}_{2} \mathrm{O}\right)$ depending on oat grain yield $\left(\mathrm{kg} \mathrm{ha}^{-1} / \mathrm{kg} \mathrm{ha}^{-1}\right)$. 


\section{Conclusion}

The application of HA with $\mathrm{Zn}$ had a positive effect on soil organic matter and nutrient content. The yields of cereals are higher when planted in winter. However, the results revealed that satisfactory oat yield can be obtained in the spring sowing with $\mathrm{HA}$ and $46 \mathrm{~kg} \mathrm{ha}^{-1} \mathrm{ZnSO}_{4} .7 \mathrm{H}_{2} \mathrm{O}$ applications. In addition, higher yields could also be obtained with the HA and $\mathrm{Zn}$ applications in winter sowing. The Albatros oat variety used in this study is a spring variety, however, very high yield values were obtained when it was sowed in winter with HA and $\mathrm{Zn}$ applications. Humic acid and $\mathrm{Zn}$ application in regions with mild winter conditions enable to get higher yields using the spring oat varieties. This study should be carried out using different oat varieties in different locations for the identification of elite varieties.

\section{Acknowledgements}

The authors are thankful to the Eskisehir Osmangazi University, Faculty of Agriculture for providing experimental area and irrigation systems for this research work.

\section{Authors' contributions}

IK carried out the field studies, performed the statistical analysis and drafted the manuscript. NG conceived the study and took part in its design and coordination. Both authors read and approved the final manuscript.

\section{Conflict of interests}

Authors have no competing interests to declare.

\section{References}

1. Dokuyucu T, Peterson DM, Akkaya A. Contents of antioxidant compounds in Turkish oats: simple phenolics and avenanthramide concentrations. Cereal Chemistry. 2003;80(5):542-43. https://doi.org/10.1094/CCHEM.2003.80.5.542

2. Peterson DM, Wesenberg DM, Burrup DE, Erickson CA. Relationships among agronomic traits and grain composition in oat genotypes grown in different environments. Crop Science. https://doi.org/10.2135/cropsci2004.0063

2005;45(4):1249.

3. FAOSTAT - Food and Agriculture Organization of The United Nations data. FAO Cereal Supply and Demand Brief / Prodution Crops. Available at http://www.fao.org/worldfoodsituation/csdb/en/ and http://www.fao.org/faostat/en/\#data/QC/visualize. Accessed on Sep. 22, 2020

4. Wali AM, Badr EA, Ibrahim OM, Ghalab EG. Can humic acid replace part of the applied mineral fertilizers?-A study on two wheat cultivars grown under calcareous soil conditions. Int J Chem Tech Res. 2015;8(9):20-26.

5. Mora V, Bacaicoa E, Zamarreno AM, Aguirre E, Garnica M, Fuentes M, García-Mina JM. Action of humic acid on promotion of cucumber shoot growth involves nitrate-related changes associated with the root-to-shoot distribution of cytokinins, polyamines and mineral nutrients. Journal of Plant Physiology. 2010;167(8):633-42. https://doi.org/10.1016/j.jplph.2009.11.018

6. Eyheraguibel B, Silvestre J, Morard P. Effects of humic substances derived from organic waste enhancement on the growth and mineral nutrition of maize. Bioresource Technology. 2008;99(10):4206-12. https://doi.org/10.1016/j.biortech.2007.08.082

7. Nunes RO, Domiciano GA, Alves WS, Melo ACA, Nogueira FCS Canellas LP, Olivares FL, Zingali RB, Soares MR. Evaluation of the effects of humic acids on maize root architecture by labelfree proteomics analysis. Scientific Reports. 2019;9(1):1-11. https://doi.org/10.1038/s41598-019-48509

8. Cakmak I, Kalayci M, Ekiz H, Braun HJ, Yilmaz A, Zinc deficiency as an actual problem in plant and human nutrition in Turkey: A NATO-Science for Stability Project. Field Crops Res. 1999;60:175-88.

9. Marschner H. Mineral Nutrition of Higher Plants. 1995; Academic Press, London.

10. Alloway BJ. Zinc in Soils and Crop Nutrition. (2nd ed) International Zinc Association, Brussels; International Fertilizer Industry Association, 2008; Paris.

11. Cakmak I, Yilmaz A, Ekiz H, Torun B, Erenoglu B, Braun HJ Zinc deficiency as a critical nutritional problem in wheat productionin Central Anatolia. Plant and Soil.1996;180:165-72.

12. Dobermann A. Nutrient use efficiency - measurement and management. In: Krauss, A., Isherwood, K., Heffer, P. (eds.), IFA International Workshop on Fertilizer Best Management Practices (Proceedings), 7-9 March 2007; Brussels, Belgium, 2007; pp. 1-28. Paris, France: International Fertilizer Industry Association.

13. López-Valdez F, Fernández-Luqueño F, Luna-Guido ML, Marsch R, Olalde-Portugal V, Dendooven L. Microorganisms in sewage sludge added to an extreme alkaline saline soil affect carbon and nitrogen dynamics. Applied Soil Ecology. 2010;45(3):225-31. https://doi.org/10.1016/j.apsoil.2010.04.009

14. Li Y, Fang F, Wei J, Wu X, Cui R, Li G, Zheng F, Tan D. Humic acid fertilizer improved soil properties and soil microbial diversity of continuous cropping peanut: A three-year experiment. Scientific Reports. 2019;9(1):1-9. https://doi.org/10.1038/s41598-019-48620-4

15. Reynolds MP, Nagarajan S, Razzaque MA, Ageeb OAA. Hea Tolerance. Application of Physioloji in Wheat Breeding. 2001;10:124-35.

16. Ram K, Munjal R, Sunita P, Kumar N. Evaluation of chlorophyll content index and normalized difference vegetation index as indicators for combine effects of drought and high temperature in bread wheat genotypes. Glob J Bio Sci Biotec. 2017;6(3):528-37.

17. Dwivedi SK, Kumar S, Mishra IS, Haris AA, Singh SK, Srivastava AK, Kumar A, Kumar V, Singh S, Bhatt BP. Effect of moisture regimes and sowing dates on wheat physiological process and yield attributes under rain-fed ecosystem in Eastern Indo Gangetic Plain. Plant Physiology Reports. 2019; 24(1):46-53. https://doi.org/10.1007/s40502-018-0406-4

18. Zvezdanović J, Marković D. Copper, iron, and zinc interactions with chlorophyll in extracts of photosynthetic pigments studied by VIS spectroscopy. Russian Journal of Physical Chemistry A.2009;83(9):1542-46

19. Eisvand HR, Kamaei H, Nazarian F. Chlorophyll fluorescence, yield and yield components of bread wheat affected by phosphate bio-fertilizer, zinc and boron under late-season heat stress. Photosynthetica. 2018;56(4):1287-96. https://doi.org/10.1007/s11099-018-0829-1

20. Chaab A, Savaghebi GR, Motesharezadeh B. Differences in the zinc efficiency among and within maize cultivars in a calcareous soil. Asian J Agric Sci. 2011;3:26-31.

21. Zhang L, Yan M, Li H, Ren Y, Siddique KH, Chen Y, Zhang S. Effects of zinc fertilizer on maize yield and water-use efficiency under different soil water conditions. Field Crops Research. https://doi.org/10.1016/j.fcr.2020.107718

22. Clemens S. Toxic metal accumulation, responses to exposure and mechanisms of tolerance in plants. Biochimie. 2006;88:1707-19. https://doi.org/10.1016/j.biochi.2006.07.003

23. Broadley MR, White PJ, Hammond JP, Zelko I, Lux A. Zinc in plants. New Phytol. 2007;173:677-702. https://doi.org/10.1111/j.1469-8137.2007.01996.x 
24. Unlu HO, Unlu H, Karakurt Y. Changes in fruit yield and quality in response to foliar and soil humic acid application in cucumber. Scientific Research and Essays. 2011;6(13):2800-03. https://doi.org/10.5897/SRE11.304

25. Fan HM, Wang XW, Sun X, Li YY, Sun XZ, Zheng CS. Effects of humic acid derived from sediments on growth, photosynthesis and chloroplast ultrastructure in Chrysanthemum. Scientia Horticulturae. 2014;177:118-123. https://doi.org/10.1016/j.scienta.2014.05.010

26. Akcin A, Akcin TA. Protective effects of humic acid on chlorophyll and malondialdehyde content in a bread wheat (Triticum aestivum L. cv. Delabrad-2) treated with chromium stress. Journal of International Environmental Application and Science. 2019;14(2):50-58.

27. Wu X, Wang Z, Chang X, Jing R. Genetic dissection of the developmental behaviours of plant height in wheat under diverse water regimes. Journal of Experimental Botany. 2010;61(11):2923-37. https://doi.org/10.1093/jxb/erq117

28. Akhtar K, Khan A, Jan MT, Afridi MZ, Ali S, Zaheer S. Effect of humic acid and crop residue application on emergence and wheat phenology. Pure and Applied Biology. 2015;4(1):97.

29. Khan M, Fuller M, Baloch F. Effect of soil applied zinc sulphate on wheat (Triticum aestivum L.) grown on a calcareous soil in Pakistan. Cereal Res Commun. 2008;36:571-82. https://doi.org/10.1556/crc.36.2008.4.6

30. Liu DY, Zhang W, Pang LL, Zhang YQ, Wang XZ, Liu YM, Zou CQ. Effects of zinc application rate and zinc distribution relative to root distribution on grain yield and grain $\mathrm{Zn}$ concentration in wheat. Plant and Soil. 2017;411(1-2):167-78.

31. Rasool G, Wahla AJ, Nawaz M, Abdur Rehman M. Determination and evaluation of the effect of different doses of humic acid on the growth and yield of wheat (Triticum aestivum L.). IOSR Journal of Agriculture and Veterinary Science (IOSR-JAVS). 2015; e.8(2):05-07.

32. Baležentienė L, Spruogis, V. Winter wheat morphology response to cold temperature stress during autumn acclimation. Modern Phytomorphology. 2013;2:23-28.

33. Kaya M, Atak M, Khawar KM, Ciftci CY, Ozcan S. Effect of presowing seed treatment with zinc and foliar spray of humic acids on yield of common bean (Phaseolus vulgaris L.). Int J Agric Biol. 2005;7(6):875-78.

34. Daur I. Effect of humic acid on growth, protein and mineral composition of pearl millet (Pennisetum glaucum L.) fodder. Pak J Bot. 2014;46(2):505-09.

35. Doroodian M, Sharghi Y, Alipour A, Zahedi H. Yield and yield components of wheat as influenced by sowing date and humic acid. International Journal of Natural Sciences. 2015;5(1):8-14 https://doi.org/10.3329/ijns.v5i1.28605

36. Ghasal PC, Shivay YS, Pooniya V, Choudhary M, Verma RK Response of wheat genotypes to zinc fertilization for improving productivity and quality. Archives of Agronomy and Soil Science. 2017;63(11):1597-12. https://doi.org/10.1080/03650340.2017.1289515

37. Hatami H. The effect of zinc and humic acid applications on yield and yield components of sunflower in drought stress. Journal of Advanced Agricultural Technologies, 2017;4 https://doi.org/10.18178/joaat.4.1.36-39

38. Yin $\mathrm{H}$, Gao X, Stomph T, Li L, Zhang F, Zou C. Zinc concentration in rice (Oryza sativa L.) grains and allocation in plants as affected by different zinc fertilization strategies. Communications in Soil Science and Plant Analysis. 2016; 47(6):761-68. https://doi.org/10.1080/00103624.2016.1146891

39. Gonzalez D, Almendros P, Obrador A, Alvarez JM. Zinc application in conjunction with urea as a fertilization strategy for improving both nitrogen use efficiency and the zinc biofortification of barley. Journal of the Science of Food and Agriculture. https://doi.org/10.1002/jsfa.9681

2019;99(9):4445-51.

40. Anonymous. Interpreting your soil test results. https://cropnuts.helpscoutdocs.com/article/829-interpretingyour-soil-test-results, Accessed on Sep. 22, 2020.

41. Zanin L, Tomasi N, Cesco S, Varanini Z, Pinton R. Humic substances contribute to plant iron nutrition acting as chelators and biostimulants. Frontiers in Plant Science. 2019;10:675. https://doi.org/10.3389/fpls.2019.00675 